Article

\title{
Efficaciousness of Low Affinity Compared to High Affinity TSPO Ligands in the Inhibition of Hypoxic Mitochondrial Cellular Damage Induced by Cobalt Chloride in Human Lung H1299 Cells
}

\author{
Nidal Zeineh ${ }^{1,+}$, Nunzio Denora ${ }^{2,3,+}$, Valentino Laquintana ${ }^{2}{ }^{\oplus}$, Massimo Franco ${ }^{2}$, \\ Abraham Weizman ${ }^{4,5}$ and Moshe Gavish ${ }^{1, *}$ \\ 1 The Ruth and Bruce Rappaport Faculty of Medicine, Technion Institute of Technology, Haifa 31096, Israel; \\ nidalz1988@gmail.com \\ 2 Department of Pharmacy-Pharmaceutical Sciences, University of Bari “Aldo Moro”, 70125 Bari, Italy; \\ nunzio.denora@uniba.it (N.D.); valentino.laquintana@uniba.it (V.L.); massimo.franco@uniba.it (M.F.) \\ 3 Institute for Chemical and Physical Processes (IPCF)-CNR SS Bari, Via Orabona 4, 70126 Bari, Italy \\ 4 Research Unit at Geha Mental Health Center and Laboratory of Biological Psychiatry at Felsenstein Medical \\ Research Center, Petah Tikva 4910002, Israel; weizmana@gmail.com \\ 5 Sackler Faculty of Medicine, Tel Aviv University, Tel Aviv 6997801, Israel \\ * Correspondence: mgavish@technion.ac.il; Tel.: +972-4829-5275; Fax: +972-4829-5330 \\ + These authors contributed equally to this work.
}

Received: 5 April 2020; Accepted: 30 April 2020; Published: 2 May 2020

check for updates

\begin{abstract}
The $18 \mathrm{kDa}$ translocator protein (TSPO) plays an important role in apoptotic cell death, including apoptosis induced by the hypoxia mimicking agent cobalt chloride $\left(\mathrm{CoCl}_{2}\right)$. In this study, the protective effects of a high $(\mathrm{CB} 86 ; \mathrm{Ki}=1.6 \mathrm{nM})$ and a low $(\mathrm{CB} 204 ; \mathrm{Ki}=117.7 \mathrm{nM})$ affinity TSPO ligands were investigated in $\mathrm{H} 1299$ lung cancer cell line exposed to $\mathrm{CoCl}_{2}$. The lung cell line H1299 was chosen in the present study since they express TSPO and able to undergo programmed cell death. The examined cell death markers included: ATP synthase reversal, reactive oxygen species (ROS) generation, mitochondrial membrane potential $(\Delta \psi \mathrm{m})$ depolarization, cellular toxicity, and cellular viability. Pretreatment of the cells with the low affinity ligand CB204 at a concentration of $100 \mu \mathrm{M}$ suppressed significantly $\left(p<0.05\right.$ for all) $\mathrm{CoCl}_{2}$-induced cellular cytotoxicity $(100 \%)$, ATP synthase reversal $(67 \%)$, ROS generation $(82 \%), \Delta \psi \mathrm{m}$ depolarization $(100 \%)$, reduction in cellular density $(97 \%)$, and also increased cell viability $(85 \%)$. Furthermore, the low affinity TSPO ligand CB204, was harmless when given by itself at $100 \mu \mathrm{M}$. In contrast, the high affinity ligand (CB86) was significantly effective only in the prevention of $\mathrm{CoCl}_{2}$-induced $\mathrm{ROS}$ generation $(39 \%, p<0.001)$, and showed significant cytotoxic effects when given alone at $100 \mu \mathrm{M}$, as reflected in alterations in ADP/ATP ratio, oxidative stress, mitochondrial membrane potential depolarization and cell death. It appears that similar to previous studies on brain-derived cells, the relatively low affinity for the TSPO target enhances the potency of TSPO ligands in the protection from hypoxic cell death. Moreover, the high affinity TSPO ligand CB86, but not the low affinity ligand CB204, was lethal to the lung cells at high concentration $(100 \mu \mathrm{M})$. The low affinity TSPO ligand CB204 may be a candidate for the treatment of pulmonary diseases related to hypoxia, such as pulmonary ischemia and chronic obstructive pulmonary disease COPD.
\end{abstract}

Keywords: translocator protein (TSPO); $\mathrm{CoCl}_{2} ;$ mitochondrial membrane potential; reactive oxygen species (ROS); cell viability; cell death; lung cancer cell line 


\section{Introduction}

In this study the hypoxic toxic agent cobalt chloride $\left(\mathrm{CoCl}_{2}\right)$ was used to induce hypoxic death in H1299 lung cancer cells. Hypoxia is a state in which the oxygen supply to a tissue within an organ is compromised [1]. Decreased oxygen levels or tension in a tissue results in hypoxic damage due to altered cellular signaling networks. Hypoxia may occur both in physiological conditions such as climbing to high altitudes, as well as in pathological conditions such as myocardial ischemia, chronic obstructive pulmonary disease (COPD), and obstructive sleep apnea [2]. Hypoxia affects cellular homeostasis, which may lead to reactive oxygen species (ROS) production, elevated vasoconstrictive substances, increased expression of pro-inflammatory cytokines, and increased intercellular and vascular cell adhesion molecules [3-9]. Impaired protein homeostasis in the muscle system is a well-known condition in COPD patients [10-12].

$\mathrm{CoCl}_{2}$ mimics hypoxic state when applied to cell cultures [13-19]. Previous studies in neural-derived PC12 cells, demonstrated that $\mathrm{CoCl}_{2}$ might induce apoptotic cell death via the P38-MAPK-caspase 3 pathway [20]. $\mathrm{CoCl}_{2}$ interferes with heme production from protoporphyrin IX (PPIX) [19,21]. PPIX acts as an endogenous ligand for the mitochondrial $18 \mathrm{kDa}$ translocator protein (TSPO) [22]. It was shown that decreased ROS levels due to TSPO knockdown lead to accumulation of PPIX and consequently increased heme production [23]. The hypoxia mimicking effect of $\mathrm{CoCl}_{2}$ is related to its stabilizing effect on the $\alpha$-subunit of HIF (hypoxia inducible transcription factor), in addition to inhibition of cytochrome-C oxidase subunit 4 (COX4) precursor processing and enhancement of its degradation [16].

Mitochondria are involved in some of the hypoxia-induced cellular injury mechanisms, and it acts as an energy source, as well as a source for metabolic signals, cellular proliferation, inflammation, and intrinsic cell death [24]. The TSPO located in the outer mitochondrial membrane plays an important role in the mitochondrial apoptotic processes [25-29], along with other cellular roles [30-32]. A previous study has indicated the role of TSPO in $\mathrm{CoCl}_{2}$-induced apoptotic cell death. TSPO knockdown in U118MG glioblastoma cells, demonstrated the important role of TSPO in apoptosis induced by $\mathrm{CoCl}_{2}$, including processes such as: $\Delta \psi \mathrm{m}$ depolarization, cardiolipin peroxidation, and ROS generation. Administration of the TSPO ligand PK 11195 inhibited partially a sequence of TSPO-related processes relevant to $\mathrm{CoCl}_{2}$-induced cell death reminiscent of the effects of TSPO knockdown determined in the same study [22]. In the present study, TSPO ligands characterized by a 2-phenyl-imidazo [1-a] pyridine nucleus (Scheme 1) that express various affinities were investigated (Table 1). The goal of the current study was to examine, for the first time, the protective effect of two novel TSPO ligands (CB86 and CB204), in the attenuation of the hypoxic effect of $\mathrm{CoCl}_{2}$ in $\mathrm{H} 1299$ lung cancer cell line. The two ligands differ in their affinity to TSPO: CB204 has low affinity $(\mathrm{Ki}=117.7 \mathrm{nM})$ and CB86 has high affinity $(\mathrm{Ki}=1.6 \mathrm{nM})$ [33]. Among the few examples known of TSPO ligands containing hydrophilic groups, there is the 8-amino imidazopyridine CB86 ligand. In a previous study it was evaluated whether further polar substituents or ionizable functional groups could be introduced on the amino group of CB86 [33]. Data indicated that introduction of a -COOH group led to a significant decrease in affinity to TSPO, as observed for the compound CB204. Furthermore, in addition to the structure-activity relationship studies, reported by some of us, highlighting the main physicochemical factors eliciting the binding of imidazopyridines to TSPO, the pharmacological profile of these compounds by measuring their modulatory effects on the $\mathrm{GABA}_{\mathrm{A}}$ receptors was also explored [33]. 
<smiles>CCCN(CCC)C(=O)Cc1c(-c2ccc(Cl)cc2)nc2c(N)cccn12</smiles>

CB86<smiles>CCCN(CCC)C(=O)Cc1c(-c2ccc(Cl)cc2)nc2c(NC(=O)CC(=O)O)cccn12</smiles>

CB199<smiles>CCCN(CCC)C(=O)Cc1c(-c2ccc(Cl)cc2)nc2c(NC(=O)CCC(=O)O)cccn12</smiles>

CB194<smiles>CCCN(CCC)C(=O)Cc1c(-c2ccc(Cl)cc2)nc2c(NC(=O)CCCC(=O)O)cccn12</smiles>

CB204<smiles>CCCN(CCC)C(=O)Cc1c(-c2ccc(Cl)cc2)nc2ccc(Cl)cn12</smiles>

\section{Alpidem}

Scheme 1. Molecular structure of CB86, CB194, CB199, CB204, and Alpidem assayed in the present study.

Table 1. The affinity data of translocator protein (TSPO) ligands used in the current study.

\begin{tabular}{cccccc}
\hline Ligand Name & CB86 & CB194 & CB199 & CB204 & Alpidem \\
\hline Molecular weight & 384 & 484 & 470 & 498 & 404 \\
TSPO $\mathrm{K}$ (nM) & 1.6 & 285.3 & 193.1 & 117.7 & 0.6 \\
\hline
\end{tabular}

CB86 and CB204 were chosen in the present study for their diverging affinities to the TSPO. This choice was prompted by previous findings with other TSPO ligands, presenting low to moderate affinity, that showed efficacy regarding cellular protective effects and without cellular toxic activity. In contrast, high affinity TSPO ligands can induce cellular toxic effects and conspicuous lethal effects at relatively high concentrations [34-36]. These previous studies were conducted on microglia, astrocytic, neuronal, and cancer cells and in animal models [35,37,38]. A previous review of numerous cell types reported that classical high affinity TSPO ligands show lethal effects at high concentrations (typically $>50 \mu \mathrm{M}$ ), but protective effects at low concentrations [39]. A subsequent experimental 
research reported that indeed in a paradigm of astrocytic cells challenged with ammonia, the classical high affinity TSPO ligands (PK 11195, Ro5 4864 and FGIN-1-27) induced cell death at concentrations above $50 \mu \mathrm{M}$, but were protective at the $\mathrm{nM}$ range [40]. Thus, the hypothesis of the present study was that the high affinity TSPO ligand (CB86 in Scheme 1) would show cytotoxic effects at a concentration of $100 \mu \mathrm{M}$, while the low affinity TSPO ligand with a comparable structure (CB204 in Scheme 1) would show cellular protective effects at the same concentration of $100 \mu \mathrm{M}$. We applied this to a paradigm of cells vastly different from the cells regularly used by us (lung cancer cells vs. brain cells). We attempted to confirm or disprove previous findings on the relationship between the affinity of ligands to TSPO and their cytotoxic or protective effects. Furthermore, the question was whether these cellular effects are specific for brain cells, or valid also for other types of cells as well, in our case lung cells. The present report provides new data since: (1) The TSPO ligands in the current study were not used in the previous studies; (2) low affinity and high affinity TSPO ligands based on a common structural framework are compared in one paradigm, so they can reliably represent their unique pharmacological properties; and (3) another type of cells (lung cells) are used, while in the previous similar studies brain derived cells were used. The present study was designed to provide indication whether the previous findings on the effects of TSPO ligands on brain derived cells can also be discerned with novel TSPO ligands when applied to other types of cells, and thus are not restricted to the cells of brain origin (microglia, astrocytes, and neuronal cells). Thus, the present attempted to verify and unify the image suggested by the scattered information of previous studies. We chose H1299 lung cells because they represent peripheral respiratory mitochondrial-relevant system, express TSPO and can undergo programmed cell death when exposed to cytotoxic agents [41].

Thus, the correlation between TSPO ligand affinity and their protective effects in a putative TSPO-associated hypoxic cellular model was evaluated in the present study.

\section{Materials and Methods}

\subsection{Study Design}

In this study, the H1299 lung cancer cells from human origin were used. The maintenance of the cells was performed according to the American Type Culture Collection (ATCC) instructions, as follows: Culture medium consisted of RPMI (high glucose, without L-glutamine and sodium pyruvate), supplemented with 10\% Fetal Bovine Serum (FBS), 2\% glutamine, and gentamycin (50 mg/mL). The serum-deprived medium contained similar components, just with $2.5 \mathrm{~mL} \mathrm{FCS} \mathrm{(0.5 \% ),} \mathrm{instead} \mathrm{of}$ $50 \mathrm{~mL}(10 \%)$. According to a previous study, hypoxic damage due to exposure to toxic agent (e.g., cigarette smoke) demonstrated an association between TSPO and apoptotic cell death. Since the conditions needed were the existence of TSPO and the possibility to induce apoptosis via TSPO, H1299 fulfilled these criteria, and were chosen in the current study [41].

The cells were incubated at $37{ }^{\circ} \mathrm{C}$ in $5 \% \mathrm{CO}_{2}$ until $80-90 \%$ confluency was reached. Initially, pretreatment of the cells with the TSPO ligands: CB86, CB194, CB199, CB204, and Alpidem, at increasing concentrations was performed $24 \mathrm{~h}$ prior to incubation with $\mathrm{CoCl}_{2}$ for another $24 \mathrm{~h}$. According to the collected results, the high affinity CB86 and the low affinity CB204 TSPO ligands were chosen for the proceeding experiments.

\section{2. $\mathrm{CoCl}_{2}$ Exposure and Its Treatment with TSPO Ligands}

According to previous studies, the $\mathrm{CoCl}_{2}$ at a concentration of $0.5 \mathrm{mM}$ was used in our experiments $[22,42,43]$.

Treatment consisted of $24 \mathrm{~h}$ of TSPO ligand pretreatment prior to the subsequent $24 \mathrm{~h}$ simultaneous exposure to $\mathrm{CoCl}_{2}$ and TSPO ligands/or vehicle. In more detail, pretreatment of the cells was conducted using DMSO (1\%) (vehicle) in serum-deprived medium for the control groups, and ligand-containing serum-deprived medium for the experimental groups. After $24 \mathrm{~h}$ of pretreatment, the medium of the control groups and the ligand-containing groups was replaced by the same medium, but in the 
"experimental groups" it contained also $0.5 \mathrm{mM} \mathrm{CoCl}_{2}$. Then, the groups of cells were incubated for another $24 \mathrm{~h}$ (the treatment), as previously described [43-45]. The pretreatment groups included: vehicle and vehicle plus ligand groups. For treatment, the groups included: Vehicle, vehicle plus ligand, vehicle plus $\mathrm{CoCl}_{2}$, and vehicle plus ligand plus $\mathrm{CoCl}_{2}$ groups. Following this subsequent exposure to $\mathrm{CoCl}_{2}$ for $24 \mathrm{~h}$, the cells were collected and processed. According to a previous study using U118MG cells [22], dose response analysis with increasing $\mathrm{CoCl}_{2}$ concentrations was performed. It was shown that at concentrations of $0.3-0.5 \mathrm{mM}$ cell death levels increased by $10-25 \%$, while at concentrations above $0.6 \mathrm{mM}$ cell death elevated by $40 \%$ to $90 \%$ [22]. In accord with the previous study [22], the $0.5 \mathrm{mM}$ concentration of $\mathrm{CoCl}_{2}$ was selected for the current experiments, in order obtain reversible and treatable cellular toxic effects. The dose response curve for $\mathrm{H} 1299$ cells exposed to $\mathrm{CoCl}_{2}$ was very similar to the one described by us previously on U118MG cells [22].

\subsection{ADP/ATP Ratio}

White 96-well plates were used to measure the levels of ADP and ATP. After pretreatment of cells in medium with and without $\mathrm{CB} 86$ and $\mathrm{CB} 204$, followed by $\mathrm{CoCl}_{2}$ exposure, the ADP/ATP ratio was measured and calculated, according to the manufacturer's protocol (MAK135; Sigma-Aldrich, St. Louis, MO, USA), as previously described [46]. Luminescence levels of the ratio between ADP and ATP were measured by ELISA using Infinite M200 Pro plate reader (Tecan, Männedorf, Switzerland), according to the instructions of the manufacturer.

\subsection{Reactive Oxygen Species (ROS) Levels}

ROS/superoxide detection assay kit (Abcam, Cambridge, UK) was used to measure ROS and superoxide levels according to the manufacturer's instructions. Following treatment of the cells as described above, they were washed using $1 \mathrm{X}$ wash buffer followed by application of $100 \mu \mathrm{L} /$ well of ROS/superoxide detection solution and then incubated in dark for $60 \mathrm{~min}$. ELISA with Infinite M200 Pro plate reader (Tecan, Männedorf, Switzerland) was used with standard fluorescein (excitation $488 \mathrm{~nm}$ and emission $520 \mathrm{~nm}$ ) and rhodamine (excitation $550 \mathrm{~nm}$ and emission $610 \mathrm{~nm}$ ) filter sets, and fluorescence levels were measured, according to the instructions of the manufacturer.

\subsection{Depolarization of the Mitochondrial Membrane Potential ( $\triangle \Psi m$ )}

Mitochondrial membrane potential $(\Delta \Psi \mathrm{m})$ depolarization was assayed using the dye JC-1(5,5',6,6' -tetrachloro-1,1',3,3'-tetraethylbenzimidazolylcarbocyanine-chloride), as described previously [22]. JC-1 is a marker for mitochondrial function and cell health. Intact cells characterized by high $\Delta \psi_{\mathrm{M}}$, the cationic lipophilic JC-1 dye selectively enters the mitochondria, forms aggregates and thus reversibly changes color from green to red inside the mitochondria (orange-red fluorescence emitting at $590 \mathrm{~nm}$ wavelength). In case of $\Delta \psi_{\mathrm{M}}$ depolarization, monomers of JC-1 remain in the cytoplasm, and these monomers emit at $527 \mathrm{~nm}$ (green fluorescence). Thus, $\Delta \psi_{\mathrm{M}}$ depolarization is expressed by decreased red/green ratio.

The cells were trypsinized and collected by centrifugation $\left(660 \times g, 5 \mathrm{~min}, 4^{\circ} \mathrm{C}\right)$. The proton ionophore carbonyl cyanide was used as a positive control, as previously described [22]. The samples were incubated in $400 \mu \mathrm{L}$ of diluted JC-1 dye (1/500) for $30 \mathrm{~min}$. Then, the cells were centrifuged $\left(660 \times g, 5 \mathrm{~min}, 4^{\circ} \mathrm{C}\right)$, the pellets then resuspended in $500 \mu \mathrm{L}$ of PBS and transferred into FACS tubes. The mean fluorescence intensity (MFI) was measured using FACS device, and the results were analyzed using FlowJo (10th version, FlowJo LLC, Ashland, OR, USA). In the calculation of the mitochondrial depolarization the basal 590/527 ratio was subtracted. This is an assay demonstrating cell number-wise, namely, the percentage of the measured cell population presents mitochondrial depolarization sufficient to prevent JC-1 entry and conversion to red emitting aggregates. 


\subsection{Cellular Cytotoxicity Assay (LDH)}

Cellular cytotoxicity levels were measured by the Cytotoxicity Detection Kit (Roche Pharmaceuticals, Basel, Switzerland), which measures the LDH enzyme levels in the medium. LDH enzyme is released from the cells when the cell membrane is disrupted in case of necrosis and late apoptosis [47].

Cytotoxicity levels were measured by an absorbance at $492 \mathrm{~nm}$ wavelength and a reference wavelength of $620 \mathrm{~nm}$, according to the manufacturer's protocol. ELISA with spectrophotometer Zenyth 200 (Anthos, Eugendorf, Austria) was used for measurements and the results were calculated and normalized (calibrated) according to the formula given by the manufacturer.

\subsection{XTT Based Colorimetric Assay}

Cell viability was measured using XTT cell viability assay kit (Abcam, Cambridge, UK), according to the manufacturer's protocol. In this assay, in viable cells the 2,3-bis [2-methoxy-4-nitro-5-sulphophenyl]-2H-tetrazolium-5-carboxylanilide inner salt (XTT) is reduced by mitochondrial dehydrogenases, and this reaction leads to an orange formazan product. This assay measures cell metabolism as an indication of cell viability. The spectrophotometer Zenyth 200 (Anthos, Eugendorf, Austria) was used to assess optical density (OD) as reflected by absorbance at $492 \mathrm{~nm}$ wavelength and a reference wavelength of $620 \mathrm{~nm}$ (ELISA technology).

\subsection{Cell Density}

Photographs from wells of a 96-well plate with the various experimental groups were taken using a Basler scA1400-30gm camera, a CCD camera with Sony ICX285 CCD sensor (Essen Bioscience, Ann Arbor, MI, USA). The confluency of the cells was measured using the high throughput, continuous live cell imager Incucyte Zoom HD/2CLR System (Essen Bioscience, Ann Arbor, MI, USA) to assess the effects of $\mathrm{CoCl}_{2}$ exposure on the density of the cells. The same number of cells were used in each assay for all wells. To ensure this, plating was done from one tube with cell suspension by collecting equal amounts from the tube for each well. In numbers, 40,000 cells per $\mathrm{cm}^{2}$ were seeded and then the cells were cultured till they reached $80-90 \%$ confluency.

\subsection{Statistical Analysis and Data Presentation}

Relative changes (\%) were used for comparisons among assays. GraphPad prism (GraphPad Software, San Diego, CA, USA) was used for statistical analysis. The results were expressed as mean \pm SEM. One-way analysis of variance (ANOVA) was performed followed by Bonferroni's post hoc test for multiple comparisons as appropriate. $p<0.05$ was considered as statistically significant.

\section{Results}

\subsection{Screening of TSPO Ligand Efficacy in the Protection of Cellular Viability}

Assessment of the efficacy of the TSPO ligands in the prevention of $\mathrm{CoCl}_{2}$ cytotoxicity was determined using a cellular viability assay (XTT) with different TSPO ligands CB86, CB194, CB199, CB204, and alpidem, at concentrations of $1 \mu \mathrm{M}, 10 \mu \mathrm{M}, 25 \mu \mathrm{M}, 50 \mu \mathrm{M}$, and $100 \mu \mathrm{M}$ for each of them (Figure 1A-E). It was demonstrated that the high affinity CB86 ligand and the high affinity alpidem, did not protect against the cytotoxicity caused by $\mathrm{CoCl}_{2}(0.5 \mathrm{mM})$, while the low affinity $\mathrm{CB} 204$ achieved significant protective capacity by $76 \%$ at a concentration of $25 \mu \mathrm{M}$ (Figure 1C) and by $85 \%$ at $100 \mu \mathrm{M}$ (Figure 1E). In addition, the low affinity CB194 and CB199 ligands displayed significant protection by $61 \%$ and by $59 \%$, respectively, against $\mathrm{CoCl}_{2}$ cytotoxicity only at a concentration of $100 \mu \mathrm{M}$ (Figure $1 \mathrm{E}$ ). According to these data (Figure 1), the high affinity ligand CB86 and the low affinity ligand CB204 at a concentration of $100 \mu \mathrm{M}$ were chosen for further investigation of the potential effects of the affinity of the TSPO ligands in the protection from $\mathrm{CoCl}_{2}$-induced cellular damage. 

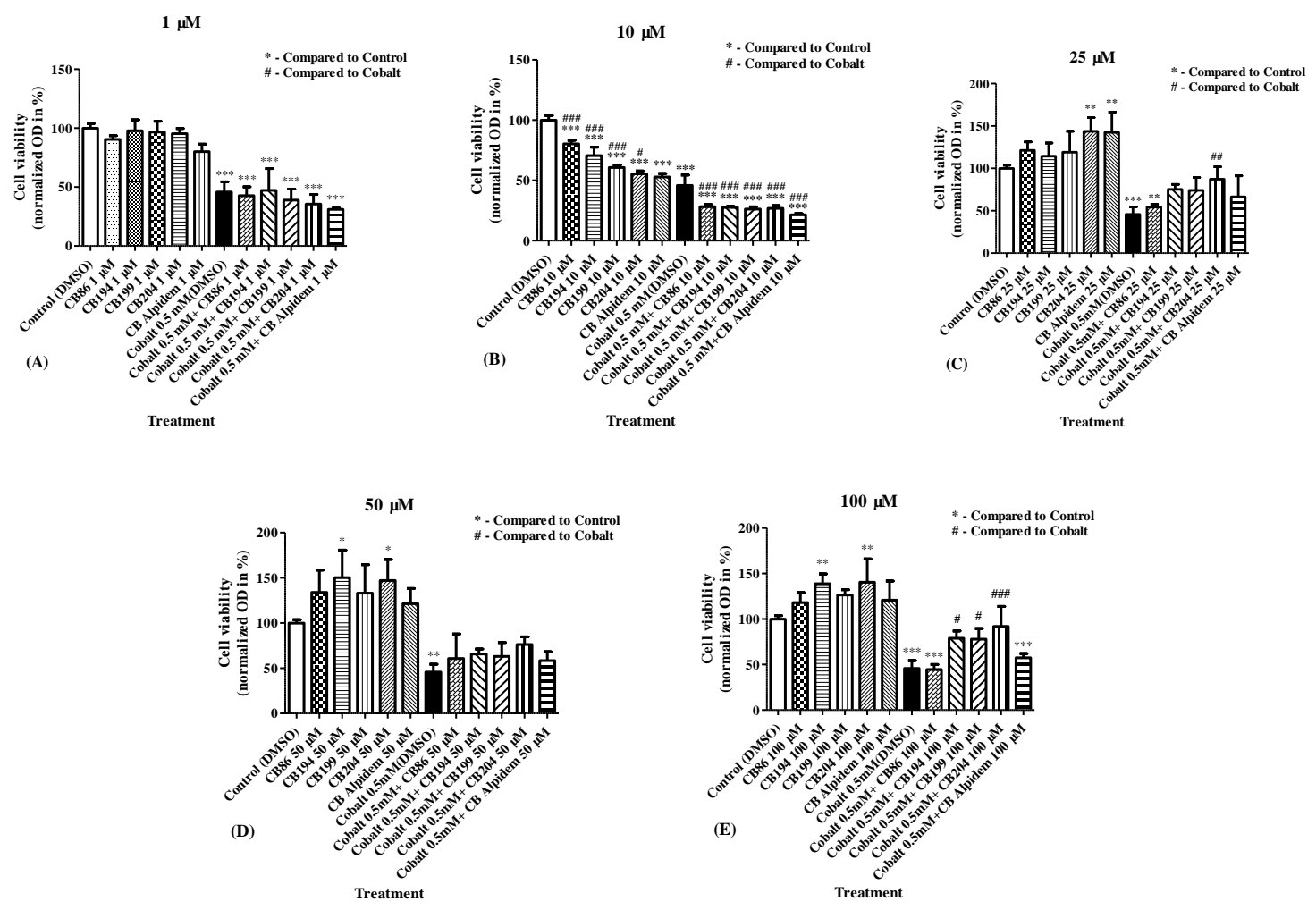

Figure 1. Determination of the ligand efficacy in inhibition of $\mathrm{CoCl}_{2}$-induced decrease in cellular viability (XTT assay). Cell viability was assessed following pretreatment with TSPO ligands at various concentrations of $1 \mu \mathrm{M}, 10 \mu \mathrm{M}, 25 \mu \mathrm{M}, 50 \mu \mathrm{M}$, and $100 \mu \mathrm{M}(\mathbf{A}-\mathbf{E})$. Results are expressed as mean \pm SEM ( $n=5$ replicates in each group). ${ }^{\#}$ and ${ }^{*} p<0.05,{ }^{\# \#}$ and ${ }^{* *} p<0.01,{ }^{\# \#}$ and ${ }^{* * *} p<0.001$.

In general, going from high affinity to low affinity TSPO ligands (Table 1) was associated with larger protective effect (Figure 1).

3.2. Dose-Response Analyses for the Efficacy of CB86 and CB204 Ligands in the Prevention of $\mathrm{CoCl}_{2}$-Induced Decrease in Cellular Viability

To verify the indications described in Figure 1, the modulatory effect of CB86 and CB204 on cell viability following exposure to $\mathrm{CoCl}_{2}$ was assessed. The range of concentrations of these two ligands was expanded, from $1 \mu \mathrm{M}$ to $100 \mu \mathrm{M}$ (Figure 1), and from $5 \mathrm{nM}$ to $100 \mu \mathrm{M}$ (Figure 2), to ensure that no major concentration-dependent effects were overlooked. Dose-response assessment was performed for CB86 and CB204 using cellular viability assay (XTT). Pretreatment with increasing concentrations of CB86 did not inhibit the cytotoxic effect of $0.5 \mathrm{mM} \mathrm{CoCl}_{2}$ at any tested concentration (Figure 2A). In contrast, the low affinity TSPO ligand CB204 at concentrations of $25 \mu \mathrm{M}$ and $100 \mu \mathrm{M}$ prevented $50 \%$ and $81 \%$ of the cellular damage, respectively (Figure 2B). At $100 \mu \mathrm{M}, \mathrm{CB} 204$ caused maintenance at control levels, i.e., cell viability was not significantly different from vehicle-exposed cells. Figures 1 and 2 show that $100 \mu \mathrm{M}$ is the optimal concentration for CB204 capacity to provide protection from $\mathrm{CoCl}_{2}$-induced cell death. 

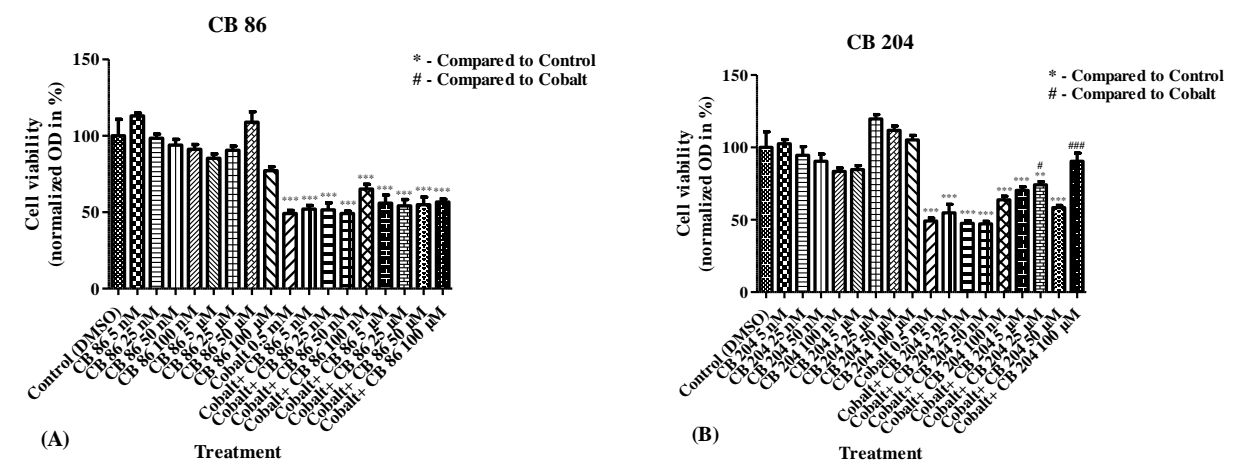

Figure 2. Dose response analysis of CB86 and CB204 ligands in inhibition of cellular viability decrease induced by $\mathrm{CoCl}_{2}$. XTT assay was performed to measure the levels of cellular viability following exposure to $\mathrm{CoCl}_{2}$ after pretreatment with (A) CB86 and (B) CB204 at increasing concentrations. Results are expressed as mean \pm SEM $\left(n=5\right.$ replicates in each group). ${ }^{\#} p<0.05$, ${ }^{\# \#}$ and ${ }^{* *} p<0.01$, \#\#\# and ${ }^{* * *} p<0.001$.

\subsection{ADP/ATP Ratio}

Following $\mathrm{CoCl}_{2}$ exposure for $24 \mathrm{~h}$, the ADP/ATP ratio significantly increased by $84 \%(p<0.001)$ as compared to the control group (absolute level of ADP/ATP luminescence ratio was 0.1). This increase was not attenuated significantly by pretreatment with CB86 at a concentration of $100 \mu \mathrm{M}(49 \% ; p>0.05)$, while pretreatment with CB204 at a concentration of $100 \mu \mathrm{M}$ significantly attenuated $(67 \% ; p<0.01)$ the increase in ADP/ATP ratio, as compared to the $\mathrm{CoCl}_{2}$-exposed group (Figure 3).

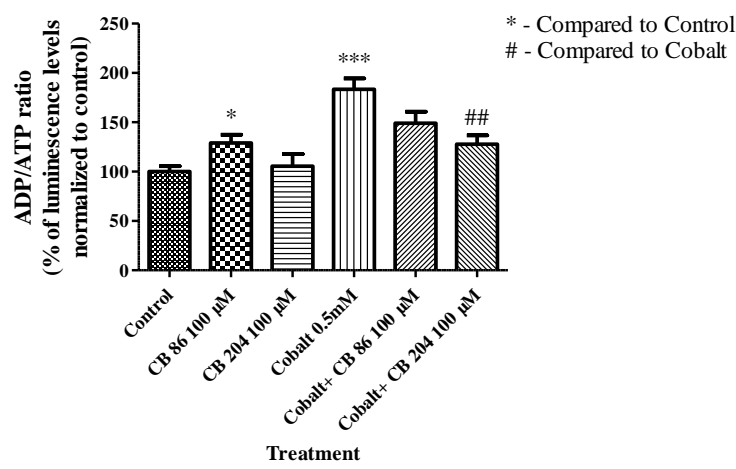

Figure 3. The ability of TSPO ligands to attenuate $\mathrm{CoCl}_{2}$-induced ATP synthase reversal. ELISA was performed to measure the alterations in ADP/ATP ratio with and without pretreatment with the TSPO ligands. Results are expressed as mean $\pm \operatorname{SEM}\left(n=5\right.$ replicates in each group). ${ }^{*} p<0.05,{ }^{\# \#} p<0.01$, and ${ }^{* * *} p<0.001$.

Regarding ADP/ATP ratio, CB86 appears to have a dual effect: slightly cytotoxic by itself, but protective from the cytotoxic effects of $\mathrm{CoCl}_{2}$. Reminiscent of the effects on ROS levels described in Section 3.4 (Figure 4). 

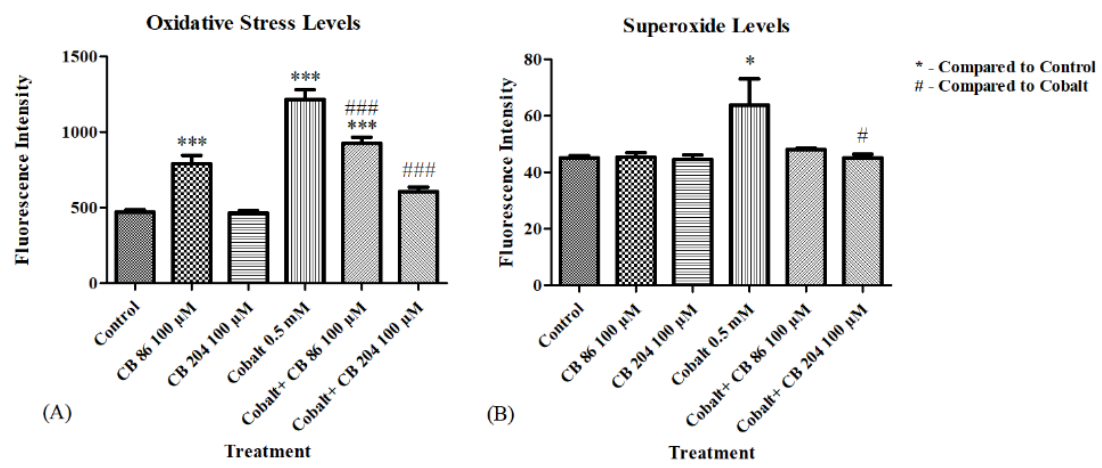

Figure 4. The protective effect of the TSPO ligands in prevention of reactive oxygen species (ROS) elevation. ELISA was performed to evaluate the levels of oxidative stress and superoxide levels. (A) Represents the oxidative stress levels, and (B) Represents the superoxide levels, with and without pretreatment with TSPO ligands. Results are expressed as mean \pm SEM ( $n=6$ replicates in each group). \# and $*<0.05$, \#\# and ${ }^{* * *} p<0.001$.

\subsection{Oxidative Stress and Superoxide Levels}

ROS levels were measured following $\mathrm{CoCl}_{2}$ exposure of CB86 and CB204 pretreated cells. Significant elevation in ROS levels was detected following pretreatment of the cells with CB86 ligand alone, while no elevation occurred following pretreatment with the TSPO ligand CB204 alone. $\mathrm{CoCl}_{2}$ induced a significant elevation in oxidative stress levels by $(158 \% ; p<0.001)$ as compared to the control group. Pretreatment with CB86 at a concentration of $100 \mu \mathrm{M}$ significantly prevented (39\%; $p<0.001$ ) of the $\mathrm{CoCl}_{2}$-induced increase in $\mathrm{ROS}$ generation, however remained significantly higher than the control $(p<0.001)$. In contrast, pretreatment with CB204 at a concentration of $100 \mu \mathrm{M}$ significantly prevented $82 \%$ of the $\mathrm{CoCl}_{2}$-induced elevation (at the control range; $p<0.001$; Figure $4 \mathrm{~A}$ ). In a second assay, superoxide levels were not elevated in response to the incubation with both ligands alone. $\mathrm{CoCl}_{2}$ exposure for $24 \mathrm{~h}$ induced a significant elevation $(41 \% ; p<0.05)$ as compared to the control group, while pretreatment with CB86 did not prevent significantly the elevation in superoxide levels ( $p>0.05$; Figure 4B). CB204 was more effective in preventing this elevation (actually to control range; $p<0.05$; Figure 4B).

\subsection{Depolarization of the Mitochondrial Membrane Potential ( $\Delta \Psi m)$}

$\Delta \Psi \mathrm{m}$ depolarization was measured by JC-1 fluorescence changes as described in the methods. Significant depolarization of the $\Delta \Psi \mathrm{m}(18 \% ; p<0.001)$ occurred after exposure to $\mathrm{CoCl}_{2}$, as compared to the control group. Pre-treatment with CB86 at a concentration of $100 \mu \mathrm{M}$ did not show any protective effect and $\triangle \Psi \mathrm{m}$ remained significantly different from the control group $(p<0.001)$. Pretreatment with CB204 prevented completely the depolarization of the $\Delta \Psi \mathrm{m}(p<0.001)$ induced by $\mathrm{CoCl}_{2}$ (Figure $5 \mathrm{~A}-\mathrm{G}$ ). Carbonyl cyanide chlorophenylhydrazone (CCCP) was used as a positive control and its administration resulted in a significant increase in depolarization of $\Delta \Psi \mathrm{m}$ (by $48 \%$ vs. control raw level; $p<0.001$ ) (Figure 5H). 

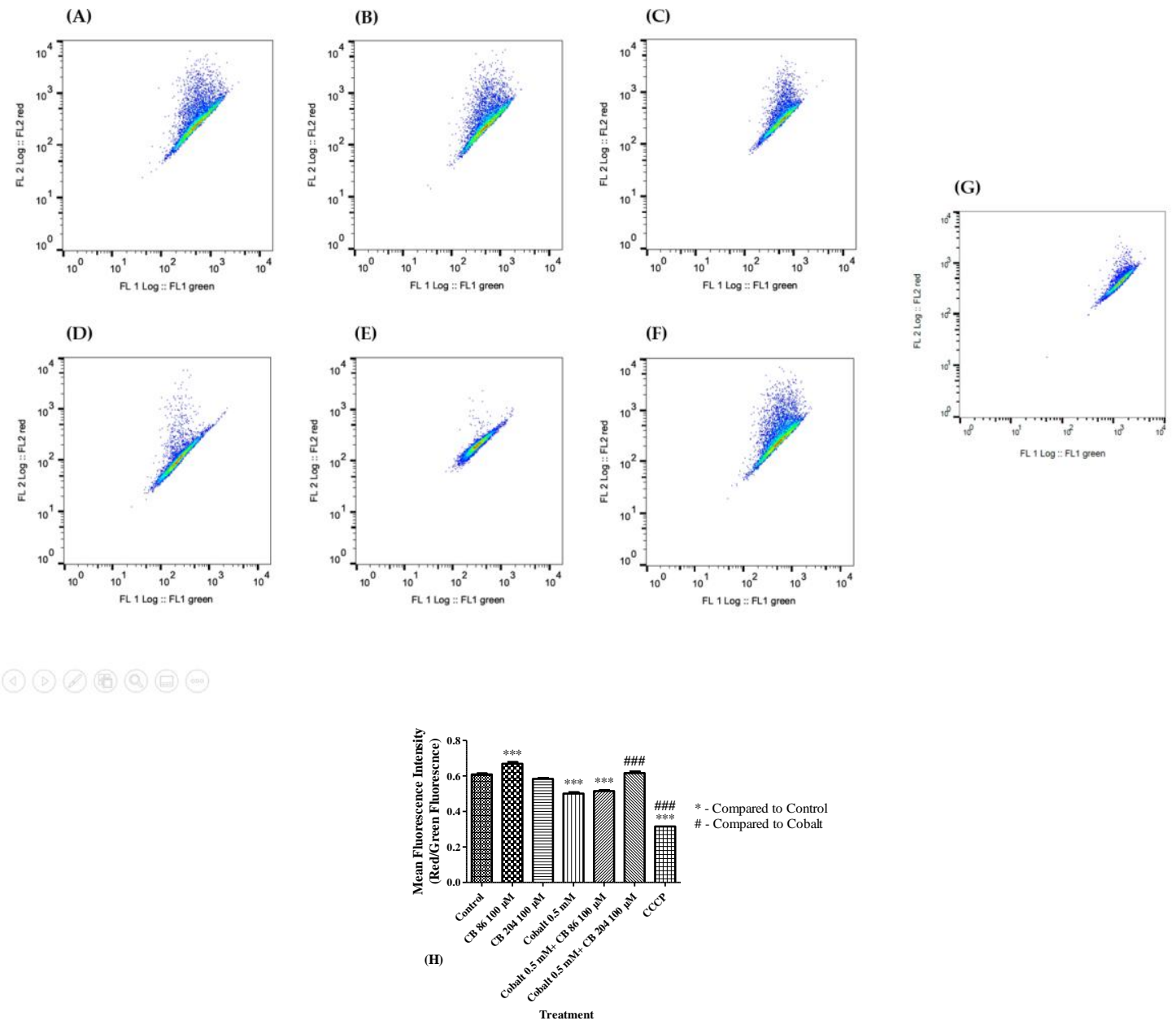

Figure 5. Comparison of the protective capacities of CB86 and CB204 in prevention of mitochondrial membrane potential depolarization. FACS was used to evaluate the $\Delta \psi \mathrm{m}$ depolarization in (A) Control group, (B) cells pretreated with CB86 alone, (C) cells pretreated with CB204 alone, (D) cells exposed to $0.5 \mathrm{mM}$ of $\mathrm{CoCl}_{2}$, (E) cells pretreated with $\mathrm{CB} 86$ and exposed to $\mathrm{CoCl}_{2}$, $(\mathrm{F})$ cells pretreated with CB204 and exposed to $\mathrm{CoCl}_{2},(\mathrm{G})$ positive control group exposed to $\mathrm{CCCP}$, and $(\mathbf{H})$ representative bar graph of the raw data. Results are expressed as mean \pm SEM ( $n=7$ replicates in each group). \#\#\# and ${ }^{* * *} p<0.001$.

\subsection{LDH Assay of Cell Death}

Cytotoxicity levels were measured by release of $\mathrm{LDH}$ enzyme into the media. $\mathrm{CoCl}_{2}$ exposure resulted in a significant elevation in cytotoxicity levels by $52 \%(p<0.001)$ as compared to the control group (absolute LDH level measured by OD was 0.5). Pretreatment with the TSPO ligand CB86 at a concentration of $100 \mu \mathrm{M}$ did not attenuate significantly the LDH elevation, while CB204 at a concentration of $100 \mu \mathrm{M}$ completely prevented the LDH elevation $(100 \% ; p<0.001)$ as compared to the $\mathrm{CoCl}_{2}$-exposed group. Both CB86 and CB204 had no effect when applied alone (Figure 6). 


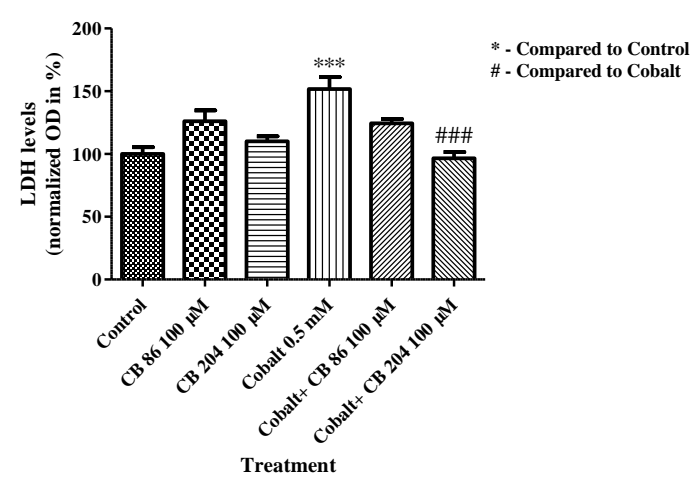

Figure 6. Prevention of $\mathrm{CoCl}_{2}$-induced cellular cytotoxicity by TSPO ligands. LDH cytotoxicity assay was performed to measure cytotoxicity levels following exposure to $\mathrm{CoCl}_{2}$ with or without TSPO ligands pretreatment. Results are expressed as mean \pm SEM ( $n=5$ replicates in each group). \#\#\# and ${ }^{* * *} p<0.001$.

\subsection{XTT Assay of Cell Viability}

Following $\mathrm{CoCl}_{2}$ exposure, cellular viability significantly decreased by $54 \%(p<0.001)$ as compared to the control group. Pretreatment with CB86 at a concentration of $100 \mu \mathrm{M}$ did not prevent the decrease in cell viability, while CB204 at a concentration of $100 \mu \mathrm{M}$ significantly prevented the decrease in cell viability as compared to the $\mathrm{CoCl}_{2}$-exposed group (85\%; $p<0.001$; Figure 7).

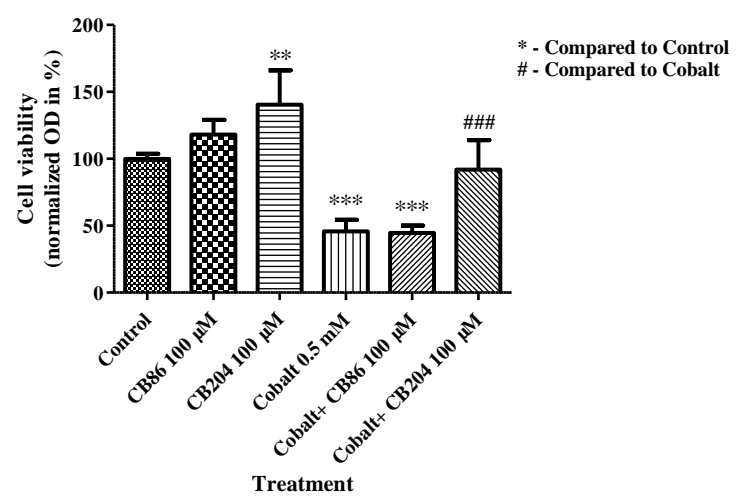

Figure 7. The protective effect of TSPO ligands in preventing the decrease in cellular viability. XTT assay was performed to measure the levels of cellular viability following $\mathrm{CoCl}_{2}$ exposure with or without TSPO ligands pretreatment. Results are expressed as mean \pm SEM ( $n=5$ replicates in each group). ** $p<0.01,{ }^{\# \#}$ and ${ }^{* * *} p<0.001$.

\subsection{Cellular Density}

Representative illustration of the alterations in cell density are depicted in Figure 8A-F. The density of the cells significantly decreased by $32 \%$ (Figure $8 \mathrm{G}$ ) following exposure to $0.5 \mathrm{mM} \mathrm{CoCl}_{2}$ for $24 \mathrm{~h}$, relative to the control group (set as 100\%) (Figure $8 \mathrm{G}$ ). The application of the high affinity ligand CB86 alone at a concentration of $100 \mu \mathrm{M}$ induced a robust reduction in cell density (by 79\%; $p<0.001$; Figure 8G). No further decrease in cell density occurred when CB86 $(100 \mu \mathrm{M})$ was applied as a pretreatment to $\mathrm{CoCl}_{2}$ exposure (by $82 \% ; p<0.001$; Figure $8 \mathrm{G}$ ). In the case of pretreatment with the low affinity ligand CB204 at a concentration of $100 \mu \mathrm{M}$, the density of the cells remained within the control range (Figure 8C). Also, when exposed to $\mathrm{CoCl}_{2}$, the pretreatment with CB204 prevented $97 \%$ of the $\mathrm{CoCl}_{2}$-induced decrease in cell density (Figure $8 \mathrm{G}$ ). The collected data are summarized in Figure 8G. 


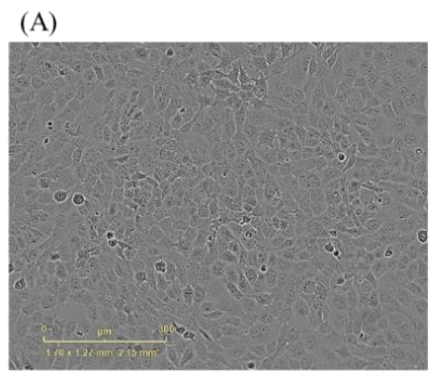

(D)

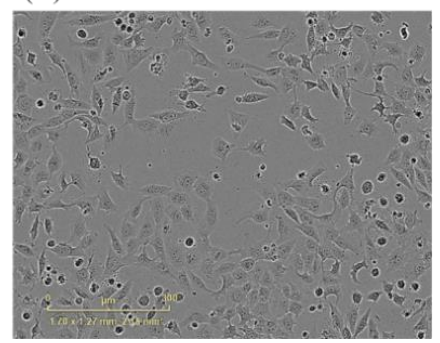

(B)

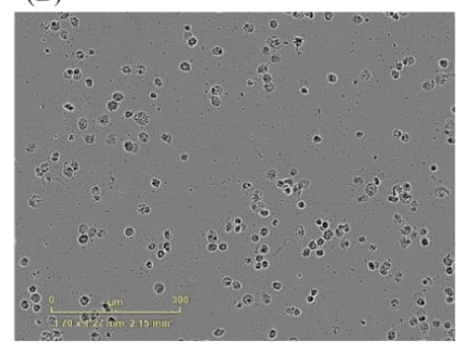

(E)
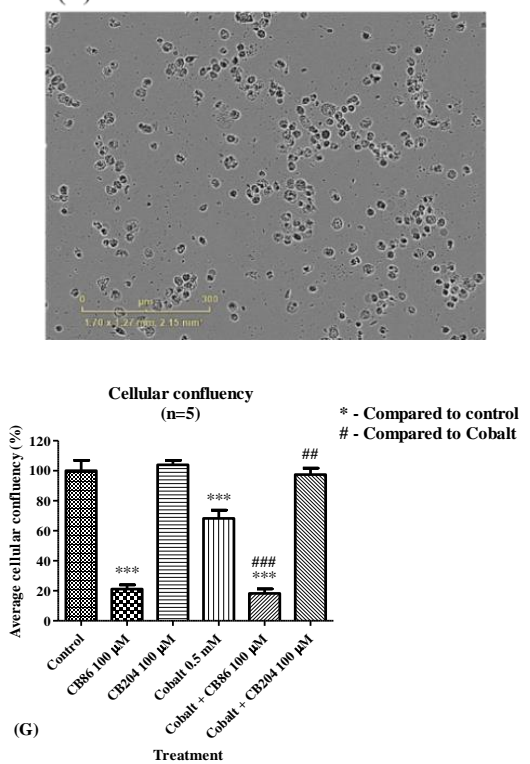

(C)

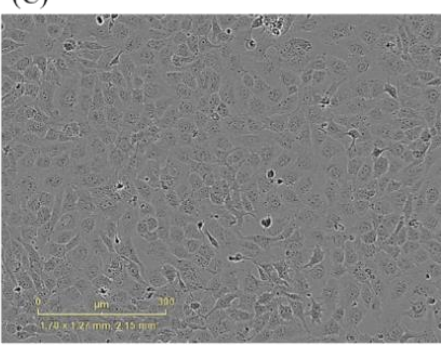

(F)

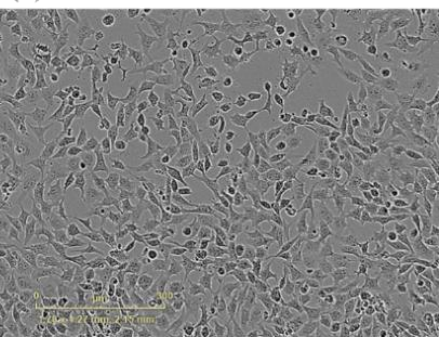

Figure 8. The effects of CB86 and CB204 on reductions of cell density caused by $\mathrm{CoCl}_{2}$. Photographs showing the density of $\mathrm{H} 1299$ cells in (A) control group, (B) following pretreatment with the high affinity CB86 ligand alone $(100 \mu \mathrm{M}),(\mathrm{C})$ following pretreatment with the low affinity CB204 ligand alone $(100 \mu \mathrm{M}),(\mathbf{D})$ following exposure to $0.5 \mathrm{mM}$ of $\mathrm{CoCl}_{2}$, (E) following pretreatment with the high affinity CB86 at a concentration of $100 \mu \mathrm{M}$ and exposure to $0.5 \mathrm{mM} \mathrm{CoCl}_{2}$, (F) following pretreatment with the low affinity CB204 at a concentration of $100 \mu \mathrm{M}$ and exposure to $0.5 \mathrm{mM} \mathrm{CoCl}_{2}$, and (G) a bar graph summarizing the results. Results in Figure $8 \mathrm{G}$ are presented as mean \pm SEM $(n=5$ replicates in each group). ${ }^{\#} p<0.01,{ }^{\# \#}$ and ${ }^{* * *} p<0.001$.

In summary, $\mathrm{CB} 86$ (with and without $\mathrm{CoCl}_{2}$ ) caused robust reductions in cell density, while CB204 alone has no harmful effect on cell density and prevented completely reductions in cell density induced by exposure $\mathrm{CoCl}_{2}$.

\subsection{Summary of the Collected Data}

As the results show (Figures 3-8), application of the high affinity TSPO ligand CB86 applied alone at a concentration of $100 \mu \mathrm{M}$ caused: (1) Increase in the ADP/ATP ratio (Figure 3); (2) increase in ROS generation, but without effect on superoxide levels (Figure 4); (3) increase in the occurrence of $\Delta \Psi \mathrm{m}$ depolarization (Figure 5); (4) increase of cell membrane disruption as assessed by LDH levels in the supernatant (Figure 6). In contrast, the low affinity TSPO ligand CB204 at the same concentration $(100 \mu \mathrm{M})$ did not induce any cytotoxic effects (Figures 3-8). The overall efficient protective effects indicate a favorable profile of the low affinity TSPO ligand CB204 (Figures 1-8) with regard to efficacy and safety in hypoxic cellular conditions. 


\section{Discussion}

In this study, we focused on the capacity of two TSPO ligands, the high affinity CB86 and the low affinity CB204 (affinity and structure presented in Table 1 and Scheme 1) to prevent cellular damage induced by $\mathrm{CoCl}_{2}$ (Figures 3-8 and Scheme 2). Based on ligand efficacy in prevention of $\mathrm{CoCl}_{2}$-induced cytotoxicity (Figure 1) and dose-response analysis (Figure 2), the high affinity CB86 ligand and the low affinity CB204 ligand at a concentration of $100 \mu \mathrm{M}$ were chosen for this study. A previous study demonstrated the protective effects of the high affinity TSPO ligand PK 11195 $(25 \mu \mathrm{M})$, in $\mathrm{CoCl}_{2}$-induced cell death, which was reminiscent to the protective effect of TSPO gene knockdown [22]. The protective effect of the TSPO ligands was established in several $\mathrm{CoCl}_{2}$-induced cytotoxic assays, including ADP/ATP ratio, ROS generation, superoxide levels, LDH cytotoxicity assay, cellular viability assay (XTT), and viable cell density. The low affinity ligand CB204 significantly inhibited the cytotoxic effect of $\mathrm{CoCl}_{2}$ on $\mathrm{H} 1299$ lung cells in all the tested assays (Figures 3-8), furthermore, it was harmless when given alone. In contrast, the high affinity ligand CB86 was ineffective in the prevention of the cytotoxicity in most of the assays, except ROS generation. Moreover, CB86 was harmful when given alone in the assay of density of viable cells (Figure 8). Our results show that the effects of TSPO ligands reported in brain cells, are not restricted to cells of the central nervous system $[35,37,38]$, but also applicable to lung cancer cells. It would be interesting to test whether this could be true for other types of cells as well.

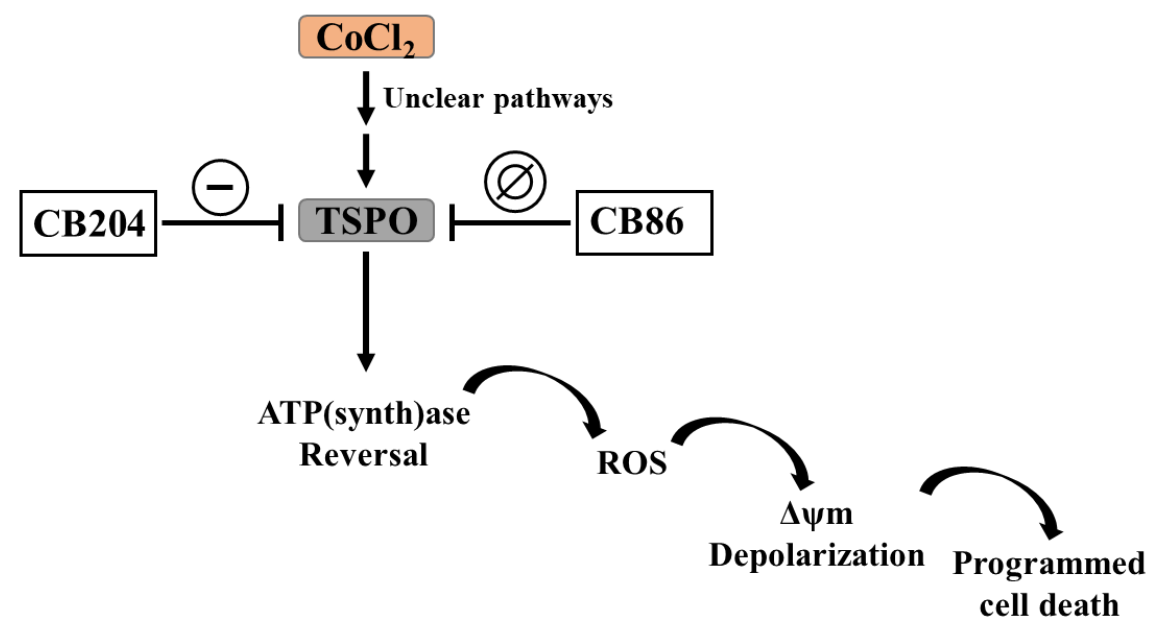

Scheme 2. The capacity of TSPO ligand to inhibit the initiation of the $\mathrm{CoCl}_{2}$ cytotoxic effect and its propagation towards mitochondrial apoptosis cascade. The progression was inhibited by the low affinity CB204, but not by the high affinity CB86, TSPO ligands.

The difference in the protective capacity of the two ligands could be related to differences in their affinity to TSPO or could be related to their putative agonistic or antagonistic activities at the TSPO. Several studies attempted to identify the agonistic or antagonistic properties of TSPO ligands and to sort them as agonists and antagonists. Unfortunately, such classification of TSPO ligands was abandoned, since the same ligand may exert an agonistic activity or an antagonistic activity, depending on the investigated TSPO function $[48,49]$. The present study confirms the observation that high affinity TSPO ligands can exert harmful, and even lethal, cellular effects, as was described in other paradigms [34-36]. On the other hand, most importantly, the present study supports the notion that low affinity TSPO ligands, may possess protective cellular effects and are devoid of cytotoxic effects, as was demonstrated in previous studies $[35,37,38]$.

Different ligands have varying cellular impact in nanomolar or micromolar range concentrations depending on the TSPO complex composition and the varying affinities to the TSPO complex present in a specific cell [49]. For example, the TSPO2 isoform, the main isoform at the red blood cells membrane requires micromolar concentrations for modulation of cellular functions, while the TSPO1 isoform 
requires nanomolar concentrations for modulation of cellular functions [49-52]. Such difference in specific ligand-interacting structural domains, within the TSPO protein or the protein complex, could explain the variability in the impact of TSPO ligands at different concentrations in different cell types. The presence of a high affinity and a low affinity binding sites can explain the dose-dependent dual effects of some TSPO ligands [39,40,53,54]. For example, the high affinity TSPO ligands PK 11195, Ro5-4864, and FGIN-1-27 at nanomolar concentrations protect U118MG human glioma cells from ammonia-induced cytotoxicity, while at micromolar concentrations the same ligands induce cytotoxic effects [36]. We suggest that this association between affinity of the ligands to TSPO and their protective potency regarding cell viability may be the rule rather than a coincidence. Yet, this notion should be investigated further in other cell types. The two ligands CB194 and CB199 with the lowest affinity (Table 1) did not show lethal cellular effect, but they may influence other TSPO functions. It is unclear whether these ligands act at the same ligand binding site, or at different ones. At present, only a restricted number of ligand binding sites were identified [36]. Previous studies showed that binding of the ligands might be influenced by the interaction between TSPO and the TSPO-associated proteins, such as mitochondrial voltage-dependent anion channels (or mitochondrial porins; VDAC) $[55,56]$. For example, the anticancer drugs ErPC and ErPC3, do not bind directly to TSPO, but they exert their anti-proliferative effect indirectly through TSPO [29], while TRO 19622 binds to both the TSPO and its associated protein VDAC [57].

TSPO is associated with regulation of various intracellular and mitochondrial processes. In the current study, the cytotoxic impact of CB86 on viable cellular density was accompanied by inability to protect most of the vital cellular metabolic processes. Modulation of TSPO protein expression leads to a cascade of events, including reversal of ATP synthase activity, followed by elevated ROS generation causing oxidative stress $[23,29,58,59]$, which is associated with $\Delta \psi \mathrm{M}$ depolarization, and eventually cell death (Scheme 2) [60]. Such a correlation between TSPO and cell death, mainly apoptotic cell death, was investigated previously. Exposure of U118MG glioblastoma cells to $\mathrm{CoCl}_{2}$ resulted in increased apoptotic cell death, while TSPO knockdown prevented this cytotoxic effect of $\mathrm{CoCl}_{2}$. Moreover, exposure of the cells to the proapoptotic agent $\mathrm{CoCl}_{2}$ resulted in parallel increases in TSPO expression levels, as determined by Western blot and binding capacity. The same study demonstrated the role of TSPO in cellular processes leading to apoptosis [22]. Regarding another function, apart from $\Delta \Psi \mathrm{m}$ collapse initiating the mitochondrial apoptosis cascade, TSPO via the mitochondria-to-cell-nucleus-pathway may also affect apoptosis induction due to modulation of cell nuclear gene expression for proteins that play a role in functional pathways regulating apoptosis [61]. Thus, the present observations on lung cells are similar to previous observations in brain cells, i.e., indicative of a common property, rather than a cell, tissue, or organ specific effect. However, research on different cell types, from different tissues and organs are required to further substantiate notion.

It was shown previously that $0.1-1 \mathrm{mM}$ of $\mathrm{CoCl}_{2}$ can mimic hypoxia in urinary bladder smooth muscle cells as well as cardiomyocytes [62,63]. In the current study in H1299 lung cancer cell line, it was shown that the $\mathrm{CoCl}_{2}$-induced cascade of apoptotic events demonstrated in Scheme 2, may be prevented by TSPO ligands. The results emphasize the superiority of the low affinity TSPO ligand (CB204) in preventing cell death as well the preceding cascade of events leading to cell death as compared to the high affinity ligand (CB86). Previous studies have shown that TSPO ligands affect also cell proliferation, hence, it would also be interesting to test this for CB86 and CB204. It may be assumed that different binding domains modulate different TSPO functions.

In conclusion, our study demonstrated the robust efficacy of the low affinity TSPO ligand (CB204) in the prevention of $\mathrm{CoCl}_{2}$-induced cellular damages in lung cells. The protective effect of the low affinity ligand was reflected in the inhibition of the appearance of classical makers of cytotoxicity assessed in this study. In contrast, the high affinity ligand (CB86) was effective only in the prevention of oxidative stress (ROS generation). These results may have clinical implications, namely, the potential use of the low affinity TSPO ligand CB204, but not the high affinity ligand CB86, for the treatment of lung cell pathologies related to hypoxia, such as pulmonary ischemia and COPD. 
Future studies should address the following issues: the impact of TSPO knockdown and other TSPO ligands, to clarify further the role of TSPO in the $\mathrm{CoCl}_{2}$-related cellular damage as well as the role of the TSPO ligands, preferably low affinity ligands, in the protection from non- $\mathrm{CoCl}_{2}$-related hypoxic damage. Noteworthy, the current study, as well as a similar previous study on U118MG glioblastoma cells, were conducted on cells from human origin. Thus, it would be of interest to investigate the effects of TSPO ligands on cells of other species. The mechanism underpinning the impact of $\mathrm{CoCl}_{2}$ on TSPO remains unclear (Scheme 2), further gene expression studies must be performed to identify the cellular pathways that are involved in the inhibitory effect of TSPO on in vitro and in vivo hypoxic states.

Author Contributions: Conceptualization, investigation, formal analysis, and writing-original draft preparation, N.Z.; methodology and data curation, N.Z., A.W. and M.G.; writing-review and editing, M.G., A.W., N.D., V.L. and M.F.; supervision, M.G. and A.W.; funding acquisition, M.G. and N.D. All authors have read and agreed to the published version of the manuscript.

Funding: The Israel Science Foundation is acknowledged for their support for this research (Moshe Gavish 1931/14).

Conflicts of Interest: The authors declare no conflict of interest.

\section{References}

1. Tuder, R.M.; Yun, J.H.; Bhunia, A.; Fijalkowska, I. Hypoxia and chronic lung disease. J. Mol. Med. 2007, 85, 1317-1324. [CrossRef]

2. Bensaid, S.; Fabre, C.; Fourneau, J.; Cieniewski-Bernard, C. Impact of different methods of induction of cellular hypoxia: Focus on protein homeostasis signaling pathways and morphology of C2C12 skeletal muscle cells differentiated into myotubes. J. Physiol. Biochem. 2019, 75, 367-377. [CrossRef] [PubMed]

3. Chen, D.; Fang, F.; Yang, Y.; Chen, J.; Xu, G.; Xu, Y.; Gao, Y. Brahma-related gene 1 (Brg1) epigenetically regulates CAM activation during hypoxic pulmonary hypertension. Cardiovasc. Res. 2013, 100, 363-373. [CrossRef] [PubMed]

4. Chen, D.; Yang, Y.; Cheng, X.; Fang, F.; Xu, G.; Yuan, Z.; Fang, M. Megakaryocytic leukemia 1 directs a histone H3 lysine 4 methyltransferase complex to regulate hypoxic pulmonary hypertension. Hypertension 2015, 65, 821-833. [CrossRef] [PubMed]

5. Janaszak-Jasiecka, A.; Siekierzycka, A.; Bartoszewska, S.; Serocki, M.; Dobrucki, L.W.; Collawn, J.F.; Bartoszewski, R. eNOS expression and NO release during hypoxia is inhibited by miR-200b in human endothelial cells. Angiogenesis 2018, 21, 711-724. [CrossRef] [PubMed]

6. Omura, J.; Satoh, K.; Kikuchi, N.; Satoh, T.; Kurosawa, R.; Nogi, M.; Sunamura, S. Protective Roles of Endothelial AMP-Activated Protein Kinase Against Hypoxia-Induced Pulmonary Hypertension in Mice. Circ. Res. 2016, 119, 197-209. [CrossRef] [PubMed]

7. Stenmark, K.R.; Fagan, K.A.; Frid, M.G. Hypoxia-induced pulmonary vascular remodeling: Cellular and molecular mechanisms. Circ. Res. 2006, 99, 675-691. [CrossRef]

8. $\mathrm{Xu}, \mathrm{W}$; Erzurum, S.C. Endothelial cell energy metabolism, proliferation, and apoptosis in pulmonary hypertension. Compr. Physiol. 2011, 1, 357-372.

9. Ferrero, E.; Fulgenzi, A.; Belloni, D.; Foglieni, C.; Ferrero, M.E. Cellfood improves respiratory metabolism of endothelial cells and inhibits hypoxia-induced reactive oxygen species (ros) generation. J. Physiol. Pharmacol. 2011, 62, 287-293.

10. Debigaré, R.; Marquis, K.; Côté, C.H.; Tremblay, R.R.; Michaud, A.; LeBlanc, P.; Maltais, F. Catabolic/anabolic balance and muscle wasting in patients with COPD. Chest 2003, 124, 83-89. [CrossRef]

11. Egerman, M.A.; Glass, D.J. Signaling pathways controlling skeletal muscle mass. Crit. Rev. Biochem. Mol. Biol. 2014, 49, 59-68. [CrossRef] [PubMed]

12. Langen, R.C.J.; Gosker, H.R.; Remels, A.H.V.; Schols, A.M.W.J. Triggers and mechanisms of skeletal muscle wasting in chronic obstructive pulmonary disease. Int. J. Biochem. Cell Biol. 2013, 45, 2245-2256. [CrossRef] [PubMed]

13. Goldberg, M.A.; Schneider, T.J. Similarities between the Oxygen-Sensing Mechanisms Regulating the Expression of Vascular Endothelial Growth-Factor and Erythropoietin. J. Biol. Chem. 1994, 269, 4355-4359. [PubMed] 
14. Griguer, C.E.; Oliva, C.R.; Kelley, E.E.; Giles, G.I.; Lancaster, J.R.; Gillespie, G.Y. Xanthine oxidase-dependent regulation of hypoxia-inducible factor in cancer cells. Cancer Res. 2006, 66, 2257-2263. [CrossRef] [PubMed]

15. Harris, G.K.; Shi, X. Signaling by carcinogenic metals and metal-induced reactive oxygen species. Mutat. Res. 2003, 533, 183-200. [CrossRef]

16. Hervouet, E.; Pecina, P.; Demont, J.; Vojtíšková, A.; Simonnet, H.; Houštěk, J.; Godinot, C. Inhibition of cytochrome c oxidase subunit 4 precursor processing by the hypoxia mimic cobalt chloride. Biochem. Biophys. Res. Commun. 2006, 344, 1086-1093. [CrossRef]

17. Leonard, S.S.; Harris, G.K.; Shi, X. Metal-induced oxidative stress and signal transduction. Free Radic. Biol. Med. 2004, 37, 1921-1942. [CrossRef]

18. Santore, M.T.; McClintock, D.S.; Lee, V.Y.; Budinger, G.S.; Chandel, N.S. Anoxia-induced apoptosis occurs through a mitochondria-dependent pathway in lung epithelial cells. Am. J. Physiol. Lung Cell. Mol. Physiol. 2002, 282, L727-L734. [CrossRef]

19. Vijayasarathy, C.; Damle, S.; Lenka, N.; Avadhani, N.G. Tissue variant effects of heme inhibitors on the mouse cytochrome c oxidase gene expression and catalytic activity of the enzyme complex. Eur. J. Biochem. 1999, 266, 191-200. [CrossRef]

20. Liu, J.; Zhu, Y.; Chen, S.; Shen, B.; Yu, F.; Zhang, Y.; Shen, R. Apocynin Attenuates Cobalt Chloride-Induced Pheochromocytoma Cell Apoptosis by Inhibiting P38-MAPK/Caspase-3 Pathway. Cell. Physiol. Biochem. 2018, 48, 208-214. [CrossRef]

21. Padmanaban, G.; Sarma, P.S. Cobalt toxicity and iron metabolism in Neurospora crassa. Biochem. J. 1966, 98, 330-334. [CrossRef] [PubMed]

22. Zeno, S.; Zaaroor, M.; Leschiner, S.; Veenman, L.; Gavish, M. $\mathrm{CoCl}(2)$ induces apoptosis via the $18 \mathrm{kDa}$ translocator protein in U118MG human glioblastoma cells. Biochemistry 2009, 48, 4652-4661. [CrossRef] [PubMed]

23. Zeno, S.; Veenman, L.; Katz, Y.; Bode, J.; Gavish, M.; Zaaroor, M. The 18 kDa mitochondrial translocator protein (TSPO) prevents accumulation of protoporphyrin IX. Involvement of reactive oxygen species (ROS). Curr. Mol. Med. 2012, 12, 494-501. [PubMed]

24. Tang, X.; Luo, Y.X.; Chen, H.Z.; Liu, D.P. Mitochondria, endothelial cell function, and vascular diseases. Front. Physiol. 2014, 5, 175. [CrossRef] [PubMed]

25. Kugler, W.; Veenman, L.; Shandalov, Y.; Leschiner, S.; Spanier, I.; Lakomek, M.; Gavish, M. Ligands of the mitochondrial $18 \mathrm{kDa}$ translocator protein attenuate apoptosis of human glioblastoma cells exposed to erucylphosphohomocholine. Cell. Oncol. 2008, 30, 435-450. [PubMed]

26. Levin, E.; Premkumar, A.; Veenman, L.; Kugler, W.; Leschiner, S.; Spanier, I.; Pasternak, G.W. The peripheral-type benzodiazepine receptor and tumorigenicity: Isoquinoline binding protein (IBP) antisense knockdown in the C6 glioma cell line. Biochemistry 2005, 44, 9924-9935. [CrossRef]

27. Shoukrun, R.; Veenman, L.; Shandalov, Y.; Leschiner, S.; Spanier, I.; Karry, R.; Gavish, M. The 18-kDa translocator protein, formerly known as the peripheral-type benzodiazepine receptor, confers proapoptotic and antineoplastic effects in a human colorectal cancer cell line. Pharm. Genom. 2008, 18, 977-988. [CrossRef]

28. Veenman, L.; Levin, E.; Weisinger, G.; Leschiner, S.; Spanier, I.; Snyder, S.H.; Gavish, M. Peripheral-type benzodiazepine receptor density and in vitro tumorigenicity of glioma cell lines. Biochem. Pharmacol. 2004, 68, 689-698. [CrossRef]

29. Veenman, L.; Shandalov, Y.; Gavish, M. VDAC activation by the $18 \mathrm{kDa}$ translocator protein (TSPO), implications for apoptosis. J. Bioenerg. Biomembr. 2008, 40, 199-205. [CrossRef]

30. Gavish, M.; Bachman, I.; Shoukrun, R.; Katz, Y.; Veenman, L.; Weisinger, G.; Weizman, A. Enigma of the peripheral benzodiazepine receptor. Pharmacol. Rev. 1999, 51, 629-650.

31. Papadopoulos, V.; Baraldi, M.; Guilarte, T.R.; Knudsen, T.B.; Lacapère, J.J.; Lindemann, P.; Gavish, M. Translocator protein $(18 \mathrm{kDa})$ : New nomenclature for the peripheral-type benzodiazepine receptor based on its structure and molecular function. Trends Pharmacol. Sci. 2006, 27, 402-409. [CrossRef] [PubMed]

32. Veenman, L.; Gavish, M. The peripheral-type benzodiazepine receptor and the cardiovascular system. Implications for drug development. Pharmacol. Ther. 2006, 110, 503-524. [CrossRef] [PubMed]

33. Denora, N.; Laquintana, V.; Pisu, M.G.; Dore, R.; Murru, L.; Latrofa, A.; Sanna, E. 2-Phenyl-imidazo[1,2-a]pyridine Compounds Containing Hydrophilic Groups as Potent and Selective Ligands for Peripheral Benzodiazepine Receptors: Synthesis, Binding Affinity and Electrophysiological Studies. J. Med. Chem. 2008, 51, 6876-6888. [CrossRef] [PubMed] 
34. Azrad, M.; Zeineh, N.; Weizman, A.; Veenman, L.; Gavish, M. The TSPO Ligands 2-Cl-MGV-1, MGV-1, and PK11195 Differentially Suppress the Inflammatory Response of BV-2 Microglial Cell to LPS. Int. J. Mol. Sci. 2019, 20, 594. [CrossRef]

35. Vainshtein, A.; Veenman, L.; Shterenberg, A.; Singh, S.; Masarwa, A.; Dutta, B.; Maniv, I. Quinazoline-based tricyclic compounds that regulate programmed cell death, induce neuronal differentiation, and are curative in animal models for excitotoxicity and hereditary brain disease. Cell Death Discov. 2015, 1, 1-17. [CrossRef]

36. Veenman, L.; Vainshtein, A.; Yasin, N.; Azrad, M.; Gavish, M. Tetrapyrroles as Endogenous TSPO Ligands in Eukaryotes and Prokaryotes: Comparisons with Synthetic Ligands. Int. J. Mol. Sci. 2016, 17, 880. [CrossRef]

37. Chen, Y.; Veenman, L.; Singh, S.; Ouyang, F.; Liang, J.; Huang, W.; Gavish, M. 2-Cl-MGV-1 Ameliorates Apoptosis in the Thalamus and Hippocampus and Cognitive Deficits After Cortical Infarct in Rats. Stroke 2017, 48, 3366-3374. [CrossRef]

38. Shehadeh, M.; Palzur, E.; Apel, L.; Soustiel, J.F. Reduction of Traumatic Brain Damage by Tspo Ligand Etifoxine. Int. J. Mol. Sci. 2019, 20, 2639. [CrossRef]

39. Veenman, L.; Papadopoulos, V.; Gavish, M. Channel-like functions of the 18-kDa translocator protein (TSPO): Regulation of apoptosis and steroidogenesis as part of the host-defense response. Curr. Pharm. Des. 2007, 13, 2385-2405. [CrossRef]

40. Caballero, B.; Veenman, L.; Bode, J.; Leschiner, S.; Gavish, M. Concentration-dependent bimodal effect of specific $18 \mathrm{kDa}$ translocator protein (TSPO) ligands on cell death processes induced by ammonium chloride: Potential implications for neuropathological effects due to hyperammonemia. CNS Neurol. Disord. Drug Targets 2014, 13, 574-592. [CrossRef]

41. Zeineh, N.; Nagler, R.; Gabay, M.; Weizman, A.; Gavish, M. Effects of Cigarette Smoke on TSPO-related Mitochondrial Processes. Cells 2019, 8, 694. [CrossRef] [PubMed]

42. Borcar, A.; Menze, M.A.; Toner, M.; Hand, S.C. Metabolic preconditioning of mammalian cells: Mimetic agents for hypoxia lack fidelity in promoting phosphorylation of pyruvate dehydrogenase. Cell Tissue Res. 2013, 351, 99-106. [CrossRef]

43. Kim, K.S.; Rajagopal, V.; Gonsalves, C.; Johnson, C.; Kalra, V.K. A novel role of hypoxia-inducible factor in cobalt chloride- and hypoxia-mediated expression of IL-8 chemokine in human endothelial cells. J. Immunol. 2006, 177, 7211-7224. [CrossRef] [PubMed]

44. Jones, N.M.; Kardashyan, L.; Callaway, J.K.; Lee, E.M.; Beart, P.M. Long-term functional and protective actions of preconditioning with hypoxia, cobalt chloride, and desferrioxamine against hypoxic-ischemic injury in neonatal rats. Pediatr. Res. 2008, 63, 620-624. [CrossRef] [PubMed]

45. Jung, J.Y.; Roh, K.H.; Jeong, Y.J.; Kim, S.H.; Lee, E.J.; Kim, M.S.; Kim, W.J. Estradiol protects PC12 cells against CoCl2-induced apoptosis. Brain Res. Bull. 2008, 76, 579-585. [CrossRef]

46. Wu, K.C.; Cheng, K.S.; Wang, Y.W.; Chen, Y.F.; Wong, K.L.; Su, T.H.; Leung, Y.M. Perturbation of Akt Signaling, Mitochondrial Potential, and ADP/ATP Ratio in Acidosis-Challenged Rat Cortical Astrocytes. J. Cell Biochem. 2017, 118, 1108-1117. [CrossRef]

47. Weiner, D.; Levy, Y.; Khankin, E.V.; Reznick, A.Z. Inhibition of salivary amylase activity by cigarette smoke aldehydes. J. Physiol. Pharmacol. 2008, 59 (Suppl. S6), 727-737.

48. Le Fur, G.; Vaucher, N.; Perrier, M.L.; Flamier, A.; Benavides, J.; Renault, C.; Uzan, A. Differentiation between two ligands for peripheral benzodiazepine binding sites, [3H]RO5-4864 and [3H]PK 11195, by thermodynamic studies. Life Sci. 1983, 33, 449-457. [CrossRef]

49. Marginedas-Freixa, I.; Alvarez, C.L.; Moras, M.; Hattab, C.; Bouyer, G.; Chene, A.; Ostuni, M.A. Induction of ATP Release, PPIX Transport, and Cholesterol Uptake by Human Red Blood Cells Using a New Family of TSPO Ligands. Int. J. Mol. Sci. 2018, 19, 3098. [CrossRef]

50. Canat, X.; Carayon, P.; Bouaboula, M.; Cahard, D.; Shire, D.; Roque, C.; Casellas, P. Distribution profile and properties of peripheral-type benzodiazepine receptors on human hemopoietic cells. Life Sci. 1993, 52, 107-118. [CrossRef]

51. Olson, J.M.; Ciliax, B.J.; Mancini, W.R.; Young, A.B. Presence of peripheral-type benzodiazepine binding sites on human erythrocyte membranes. Eur. J. Pharmacol. 1988, 152, 47-53. [CrossRef]

52. Ostuni, M.A.; Ducroc, R.; Peranzi, G.; Tonon, M.C.; Papadopoulos, V.; Lacapere, J.J. Translocator protein (18 kDa) ligand PK 11195 induces transient mitochondrial Ca2+ release leading to transepithelial Cl- secretion in HT-29 human colon cancer cells. Biol. Cell 2007, 99, 639-647. [CrossRef] [PubMed] 
53. Awad, M.; Gavish, M. Species differences and heterogeneity of solubilized peripheral-type benzodiazepine binding sites. Biochem. Pharmacol. 1989, 38, 3843-3849. [CrossRef]

54. Kanegawa, N.; Collste, K.; Forsberg, A.; Schain, M.; Arakawa, R.; Jucaite, A.; Halldin, C. In vivo evidence of a functional association between immune cells in blood and brain in healthy human subjects. Brain Behav. Immun. 2016, 54, 149-157. [CrossRef] [PubMed]

55. Garnier, M.A.R.T.I.N.E.; Dimchev, A.B.; Boujrad, N.O.U.R.E.D.D.I.N.E.; Price, J.M.; Musto, N.A.; Papadopoulos, V.A.S.S.I.L.I.O.S. In vitro reconstitution of a functional peripheral-type benzodiazepine receptor from mouse Leydig tumor cells. Mol. Pharmacol. 1994, 45, 201-211.

56. Veenman, L.; Leschiner, S.; Spanier, I.; Weisinger, G.; Weizman, A.; Gavish, M. PK 11195 attenuates kainic acid-induced seizures and alterations in peripheral-type benzodiazepine receptor (PBR) protein components in the rat brain. J. Neurochem. 2002, 80,917-927. [CrossRef]

57. Bordet, T.; Buisson, B.; Michaud, M.; Drouot, C.; Galea, P.; Delaage, P.; Lacapere, J.J. Identification and characterization of cholest-4-en-3-one, oxime (TRO19622), a novel drug candidate for amyotrophic lateral sclerosis. J. Pharmacol. Exp. Ther. 2007, 322, 709-720. [CrossRef]

58. Caballero, B.; Veenman, L.; Gavish, M. Role of mitochondrial translocator protein (18 kDa) on mitochondrialrelated cell death processes. Recent Pat. Endocr. Metab. Immune Drug Discov. 2013, 7, 86-101. [CrossRef]

59. Veenman, L.; Alten, J.; Linnemannstöns, K.; Shandalov, Y.; Zeno, S.; Lakomek, M.; Kugler, W. Potential involvement of F0F1-ATP(synth)ase and reactive oxygen species in apoptosis induction by the antineoplastic agent erucylphosphohomocholine in glioblastoma cell lines: A mechanism for induction of apoptosis via the $18 \mathrm{kDa}$ mitochondrial translocator protein. Apoptosis 2010, 15, 753-768.

60. Veenman, L.; Gavish, M.; Kugler, W. Apoptosis induction by erucylphosphohomocholine via the $18 \mathrm{kDa}$ mitochondrial translocator protein: Implications for cancer treatment. Anticancer Agents Med. Chem. 2014, 14, 559-577. [CrossRef]

61. Yasin, N.; Veenman, L.; Singh, S.; Azrad, M.; Bode, J.; Vainshtein, A.; Gavish, M. Classical and Novel TSPO Ligands for the Mitochondrial TSPO Can Modulate Nuclear Gene Expression: Implications for Mitochondrial Retrograde Signaling. Int. J. Mol. Sci. 2017, 18, 786. [CrossRef]

62. Sawada, N.; Yao, J.; Hiramatsu, N.; Hayakawa, K.; Araki, I.; Takeda, M.; Kitamura, M. Involvement of hypoxia-triggered endoplasmic reticulum stress in outlet obstruction-induced apoptosis in the urinary bladder. Lab. Invest. 2008, 88, 553-563. [CrossRef] [PubMed]

63. Shu, B.; Yang, W.W.; Yang, H.T. Expression pattern of E2F6 in physical and chemical hypoxia-induced apoptosis. Sheng Li Xue Bao 2008, 60, 1-10. [PubMed] 